\title{
Effect of the beta-3 adrenergic receptor Trp64Arg and uncoupling protein 1-3826 A > G genotypes on lipid and apolipoprotein levels in overweight/ obese and non-obese Chinese subjects
}

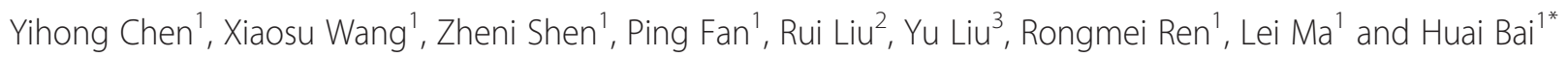

\begin{abstract}
Background: The beta-3 adrenergic receptor ( $\beta 3-A R$ ) Trp64Arg and uncoupling protein 1 (UCP1) -3826 A > G polymorphisms have been reported to be associated with obesity and/or lipid metabolism in some populations. This study examined the possible association of the $\beta 3-A R$ and UCP1 polymorphisms with overweight/obesity or lipid variation in a Southwest Chinese population.

Methods: A total of 418 Han Chinese (249 overweight/obese and 169 healthy control subjects) in the Chengdu area were studied using PCR-RFLP analysis. Total serum cholesterol (TC) and triglycerides (TGs) were measured using an enzymatic method. High density lipoprotein cholesterol (HDL-C) was determined after sodium phosphotungstate/ magnesium chloride precipitation of low-density lipoproteins by polyvinyl sulfate. Serum apolipoproteins were quantified by radial immunodiffusion.

Results: The genotype and allele frequencies of the $\beta 3-A R$ Trp64Arg and UCP1 -3826 A > G polymorphisms in overweight/obese subjects exhibited no significant differences compared to the controls. However, subjects carrying the $\beta 3-A R$ TrpTrp genotype and UCP1 AG genotype had higher TG levels than those carrying the Arg allele and AA genotype, respectively $(P<0.05)$, while controls carrying the $\beta 3-A R$ Arg allele had significantly higher $\mathrm{TC}$ and apo All concentrations than those carrying the TrpTrp genotype $(P<0.05)$. Additionally, subjects carrying the UCP1 AG genotype exhibited elevated apo C-II and apo C-III levels compared to those carrying the AA genotype $(P<0.05)$. We were unable to find an association of the UCP1 and $\beta 3-A R$ polymorphisms with low HDL-cholesterolemia in the overweight/obese subjects.
\end{abstract}

Conclusions: The present study provides evidence that the $\beta 3-A R$ Trp64Arg and UCP1 -3826 A > G polymorphisms are associated with TG levels in overweight/obese Chinese subjects and that the two polymorphisms are also associated with certain lipid and apolipoprotein variations, depending on BMI. However, these polymorphisms are not associated with overweight/obesity or low HDL-cholesterolemia in a Chinese population from the Chengdu area.

Keywords: Overweight/obese, $\beta 3-A R$, UCP1, Gene polymorphism, PCR-RFLP

\footnotetext{
* Correspondence: baihuai60@aliyun.com

'Laboratory of Genetic Disease and Perinatal Medicine and Key Laboratory of

Birth Defects and Related Diseases of Women and Children of Ministry of

Education, West China Second University Hospital, Sichuan University,

Chengdu 610041, Sichuan, PR China

Full list of author information is available at the end of the article
} 


\section{Background}

Obesity is strongly associated with an adverse dyslipidemic profile and increased risks for diabetes, hypertension, and coronary artery disease. Although this relationship has been described in detail, its pathophysiological basis remains unclear.

Studies have suggested that obesity is linked to genetic and environmental factors and that most obesitypredisposing genes encode the molecular components of the physiological systems regulating energy balance [1].

The $\beta 3-A R$ gene has been established as the principal mediator of thermogenesis in brown adipose tissue and lipolysis in white adipose tissue both in animals and humans [2-4]. A $\beta 3-A R$ Trp64Arg polymorphism decreases receptor sensitivity $[5,6]$ and may be associated with obesity and related traits $[5,7,8]$. The human uncoupling protein-1, which is expressed in brown adipose tissue, dissipates the transmitochondrial proton gradient as heat and plays an important role in energy homeostasis and thermogenesis $[9,10]$. UCP1 gene polymorphisms have been implicated in the pathogenesis of obesity and related metabolic disorders, including lipid disorders [11,12]. A -3826 A > G polymorphism within the promoter region of the UCP-1 gene is a candidate gene polymorphic site related to these disorders [13-15]. Additionally, several studies have also suggested that the UCP1 $-3826 \mathrm{~A}>\mathrm{G}$ and $\beta 3-A R$ Trp64Arg polymorphisms are related to low HDL-cholesterolemia and HDL-cholesterol levels in some populations [16-20]. However, the results of these studies were not confirmed in other studies [21-26]. Furthermore, no data concerning the relationships between the $\beta 3-A R$ Trp64Arg and UCP1 $-3826 \mathrm{~A}>\mathrm{G}$ polymorphisms and overweight/obesity and lipid profiles have been reported for a Southwest Chinese population. Therefore, we undertook this populationbased study to assess whether the $\beta 3-A R$ Trp64Arg and UCP1 -3826 A > G polymorphisms were related to overweight/obesity and lipid profiles in a Southwest Chinese population.

\section{Results}

\section{Baseline characteristics of the participants in the}

\section{population}

The lipid and lipoprotein profiles for both the overweight/obese and control groups are provided in Table 1. The serum TG, apo CII, apo C-III and apoE levels were significantly higher and the HDL-C was significantly lower in the overweight/obese group compared to the control group $(\mathrm{P}<0.05$ or $\mathrm{P}<0.01)$.

\section{Allele frequencies}

The PCR amplified fragments (containing the $\beta 3-A R$ Trp64Arg and UCP1 -3826 A > G polymorphic sites) from each sample were digested with the restriction enzyme Bst NI for the Trp64Arg site and Bcl I for the -3826 A > G
Table 1 Clinical and biochemical characteristics of the overweight/obese and control subjects $(\overline{\mathbf{x}} \pm \mathbf{s})$

\begin{tabular}{|c|c|c|c|}
\hline & $\begin{array}{l}\text { Overweight/obese } \\
(n=249)\end{array}$ & Controls $(n=169)$ & $P$ \\
\hline Age (yrs) & $55.04 \pm 10.00$ & $53.35 \pm 11.78$ & 0.115 \\
\hline Gender (M/F) & $149 / 100$ & $93 / 76$ & 0.322 \\
\hline $\mathrm{TG}(\mathrm{mmol} / \mathrm{L})$ & $2.31 \pm 1.70$ & $1.72 \pm 1.56$ & 0.000 \\
\hline $\mathrm{TC}(\mathrm{mmol} / \mathrm{L})$ & $5.43 \pm 0.92$ & $5.41 \pm 1.11$ & 0.788 \\
\hline $\mathrm{HDL}-\mathrm{C}(\mathrm{mmol} / \mathrm{L})$ & $1.17 \pm 0.32$ & $1.41 \pm 0.41$ & 0.000 \\
\hline LDL-C (mmol/L) & ${ }^{a} 3.29 \pm 0.87$ & $b_{3.26 \pm 1.04}$ & 0.821 \\
\hline apoA-l (mg/dL) & $124.20 \pm 27.96$ & $128.97 \pm 23.89$ & 0.077 \\
\hline apoA-\| (mg/dL) & $28.39 \pm 4.58$ & $29.07 \pm 6.92$ & 0.227 \\
\hline apoB100 (mg/dL) & $88.93 \pm 17.06$ & $84.04 \pm 20.93$ & 0.427 \\
\hline apoC-II (mg/dL) & $6.68 \pm 3.32$ & $5.61 \pm 3.10$ & 0.001 \\
\hline apoC-III (mg/dL) & $17.47 \pm 7.03$ & $13.09 \pm 6.17$ & 0.000 \\
\hline Apo E (mg/dL) & $5.27 \pm 1.96$ & $4.87 \pm 2.26$ & 0.043 \\
\hline $\mathrm{BMI}\left(\mathrm{kg} / \mathrm{m}^{2}\right)$ & $25.72 \pm 2.25$ & $20.74 \pm 1.60$ & 0.000 \\
\hline
\end{tabular}

Subjects with TG $>4.516 \mathrm{mmol} / \mathrm{L}(400 \mathrm{mg} / \mathrm{dL})$ were excluded when calculating the serum LDL-C levels, ${ }^{a}: n=193,{ }^{b}: n=145$.

site; then, the digested fragments were analysed by agarose gel electrophoresis.

Genotypes of the Trp64Arg and $-3826 \mathrm{~A}>\mathrm{G}$ polymorphisms were found to be in Hardy-Weinberg equilibrium in both the overweight/obese and control groups. The frequency data are presented in Table 2.

Table 2 Genotype and allele frequencies of the $\beta 3-A R$ Thr64Arg and UCP1 -3826 A > G polymorphisms in the overweight/obese and control groups

\begin{tabular}{|c|c|c|c|}
\hline & \multicolumn{3}{|l|}{ Frequencies } \\
\hline & $\begin{array}{l}\text { Overweight/Obese } \\
(n=249)\end{array}$ & $\begin{array}{l}\text { Controls } \\
(n=169)\end{array}$ & $P$ \\
\hline B3-AR Trp64Arg Genotype & & & 0.414 \\
\hline Trp Trp & $0.739(184)$ & $0.734(124)$ & \\
\hline Trp Arg & $0.253(63)$ & $0.243(41)$ & \\
\hline Arg Arg & $0.008(2)$ & $0.024(4)$ & \\
\hline Allele & & & 0.668 \\
\hline Trp & $0.865(431)$ & $0.855(289)$ & \\
\hline Arg & $0.135(67)$ & 0.145 (49) & \\
\hline UCP1 -3826 A/G Genotype & & & 0.824 \\
\hline AA & $0.249(62)$ & $0.225(38)$ & \\
\hline$A G$ & $0.454(113)$ & $0.479(81)$ & \\
\hline GG & $0.297(74)$ & $0.296(50)$ & \\
\hline Allele & & & 0.746 \\
\hline A & $0.476(237)$ & $0.464(157)$ & \\
\hline G & $0.524(261)$ & $0.536(181)$ & \\
\hline
\end{tabular}

Numbers in parentheses indicate the number of subjects with each genotype or number of alleles of each type. 
The Trp and Arg allele frequencies of the $\beta 3-A R$ gene at codon 64 in the overweight/obese and normal control groups were $0.865,0.135$ and $0.855,0.145$, respectively, while the A and G allele frequencies at the $-3826 \mathrm{~A}>\mathrm{G}$ site of the $U C P 1$ gene were $0.476,0.524$ and $0.464,0.536$, respectively. The allele frequencies of the two polymorphisms in the overweight/obese subjects were not different from those in the controls $(P>0.05)$.

Moreover, no significant difference in genotype frequencies was observed when the genotypes were divided into two categories according to the dominant model or recessive model at the $\beta 3-A R$ Trp64Arg and UCP1 -3826 $\mathrm{A}>\mathrm{G}$ sites (all $\mathrm{P}>0.05$ ). Multiple logistic regression analysis was used to assess the association of the $\beta 3-A R$ Trp64Arg and UCP1 -3826 A > G polymorphisms with overweight/obesity. Assuming a dominant or recessive inheritance model, no association of the two polymorphisms were found after adjusting for age and sex (all $\mathrm{P}>0.05$ ).

Effects of polymorphic sites of the $\beta 3-A R$ and UCP1 genes on serum concentrations of lipids and apolipoproteins

To assess the possible impact of the polymorphic sites in the $\beta 3-A R$ and $U C P 1$ genes on lipid metabolism, we analysed serum lipid and lipoprotein levels in subjects possessing the different genotypes of the Trp64Arg and -3826 A $>$ G polymorphisms in both the overweight/obese and normal control groups.

In the overweight/obese group, subjects with the TrpTrp genotype at the Trp64Arg site of the $\beta 3-A R$ gene had higher serum TG concentrations than the Arg allele carriers (TG: $2.40 \pm 1.79 \mathrm{mmol} / \mathrm{L}$ vs $1.95 \pm 1.11 \mathrm{mmol} / \mathrm{L}, \mathrm{P}<$ 0.05) (Table 3), while in the normal controls the Arg allele carriers had higher TC and apoA-II concentrations than the TrpTrp genotype carriers (all $\mathrm{P}<0.05$ ) (Table 3 ).
In the overweight/obese group, subjects with the AG genotype of the $\mathrm{A}>\mathrm{G}$ polymorphism of the $U C P 1$ gene had a higher serum mean concentration of TG, apo C-II and apo C-III compared to patients with the AA genotype (Table 4; all $\mathrm{P}<0.05$ ). No significant effect on lipid and apolipoprotein levels was observed for the UCP1 $-3826 \mathrm{~A}>\mathrm{G}$ polymorphism in the normal control subjects.

Evaluation of the relationship between polymorphic sites in the $\beta 3-A R$ and UCP1 genes and low HDL-cholesterolemia Previous studies have suggested that the UCP1 $-3826 \mathrm{~A}$ > G polymorphism was related to low HDL-cholesterolemia and low HDL-cholesterol levels in some populations with obesity. Additionally, the $\beta 3-A R$ Trp64Arg polymorphism has been shown to be related to low HDL-cholesterol levels in some ethnic groups. Therefore, we analysed the relationship between polymorphic sites in the $\beta 3-A R$ and $U C P 1$ genes and low cholesterolemia in our population.

In the overweight/obese subjects, the allele frequencies of the two polymorphisms in subjects with HDL-C < $1.04 \mathrm{mmol} / \mathrm{L}$ were not different from those with HDL$\mathrm{C} \geq 1.04 \mathrm{mmol} / \mathrm{L}$ (Table 5, both $\mathrm{P}>0.05$ ).

\section{Discussion}

Our results in the Chinese cohort living in Southwest China showed that both the polymorphisms in the $\beta 3-A R$ and $U C P 1$ genes were associated with TG concentrations in overweight/obese subjects and that the two polymorphisms were also associated with some lipid and apolipoprotein levels (i.e., TC, apoAII, apo CII and apo CIII levels) depending on BMI. However, we did not find an association between the polymorphisms and overweight/ obesity or low HDL-cholesterolemia in overweight/obese subjects. These results provide support for the notion that

Table 3 Mean values $(\overline{\mathbf{x}} \pm \mathbf{s})$ of serum lipid and apolipoprotein levels for the Thr64 Arg site of the $\beta 3-A R$ gene in the overweight/obese and control groups ${ }^{\Delta}$

\begin{tabular}{|c|c|c|c|c|}
\hline & \multicolumn{2}{|l|}{ Overweight/obese } & \multicolumn{2}{|l|}{ Controls } \\
\hline & $\operatorname{TrpTrp}(\mathrm{n}=184)$ & Trp Arg + ArgArg $(n=65)$ & $\operatorname{TrpTrp}(\mathrm{n}=124)$ & TrpArg + ArgArg $(n=45)$ \\
\hline $\mathrm{TG}(\mathrm{mmol} / \mathrm{L})$ & $2.40 \pm 1.79$ & $1.95 \pm 1.11^{\mathrm{a}, *}$ & $1.64 \pm 1.05$ & $2.05 \pm 1.54$ \\
\hline $\mathrm{TC}(\mathrm{mmol} / \mathrm{L})$ & $5.58 \pm 1.02$ & $5.33 \pm 0.77$ & $5.36 \pm 1.04$ & $5.77 \pm 1.42^{b_{,}^{*}}$ \\
\hline $\mathrm{HDL}-\mathrm{C}(\mathrm{mmol} / \mathrm{L})$ & $1.16 \pm 0.31$ & $1.24 \pm 0.36$ & $1.41 \pm 0.41$ & $1.44 \pm 0.42$ \\
\hline $\mathrm{LDL}-\mathrm{C}(\mathrm{mmol} / \mathrm{L})$ & $d_{3.32} \pm 0.91$ & $\mathrm{e}_{3.19} \pm 0.73$ & $f_{3.21 \pm 1.01}$ & $9_{3.42} \pm 1.15$ \\
\hline apoA-I (mg/dL) & $125.21 \pm 29.49$ & $124.33 \pm 21.42$ & $130.21 \pm 22.58$ & $126.13 \pm 27.23$ \\
\hline apoA-\| (mg/dL) & $28.54 \pm 4.75$ & $28.48 \pm 4.90$ & $28.53 \pm 4.21$ & $31.26 \pm 11.61^{c_{1}^{*}}$ \\
\hline apoB100 (mg/dL) & $93.44 \pm 20.74$ & $86.50 \pm 14.41$ & $89.38 \pm 21.27$ & $83.70 \pm 23.98$ \\
\hline apoC-II (mg/dL) & $6.88 \pm 3.50$ & $6.12 \pm 2.64$ & $5.52 \pm 2.95$ & $5.99 \pm 3.69$ \\
\hline apoC-III (mg/dL) & $15.92 \pm 7.53$ & $14.21 \pm 4.79$ & $13.04 \pm 5.69$ & $13.76 \pm 7.67$ \\
\hline Apo E (mg/dL) & $5.39 \pm 2.11$ & $4.95 \pm 1.42$ & $4.75 \pm 1.78$ & $5.35 \pm 3.29$ \\
\hline
\end{tabular}

${ }^{\mathrm{abc} C}$ Compared with genotype TrpTrp carriers in the same group, respectively, ${ }^{*} \mathrm{P}<0.05$.

Subjects with TG $>4.516 \mathrm{mmol} / \mathrm{L}(400 \mathrm{mg} / \mathrm{dL})$ were excluded when calculating the serum LDL-C levels, ${ }^{d}: n=142,{ }^{e}: n=51,{ }^{f}: n=108,{ }^{g}: n=37$.

${ }^{\Delta}$ Age and sex were used as covariates in the analysis to adjust for the genotype effects. 
Table 4 Mean values $(\bar{x} \pm s)$ of serum lipid and apolipoprotein levels for the -3826 A $>$ G site of the UCP1 gene in the overweight/obese and control groups ${ }^{\Delta}$

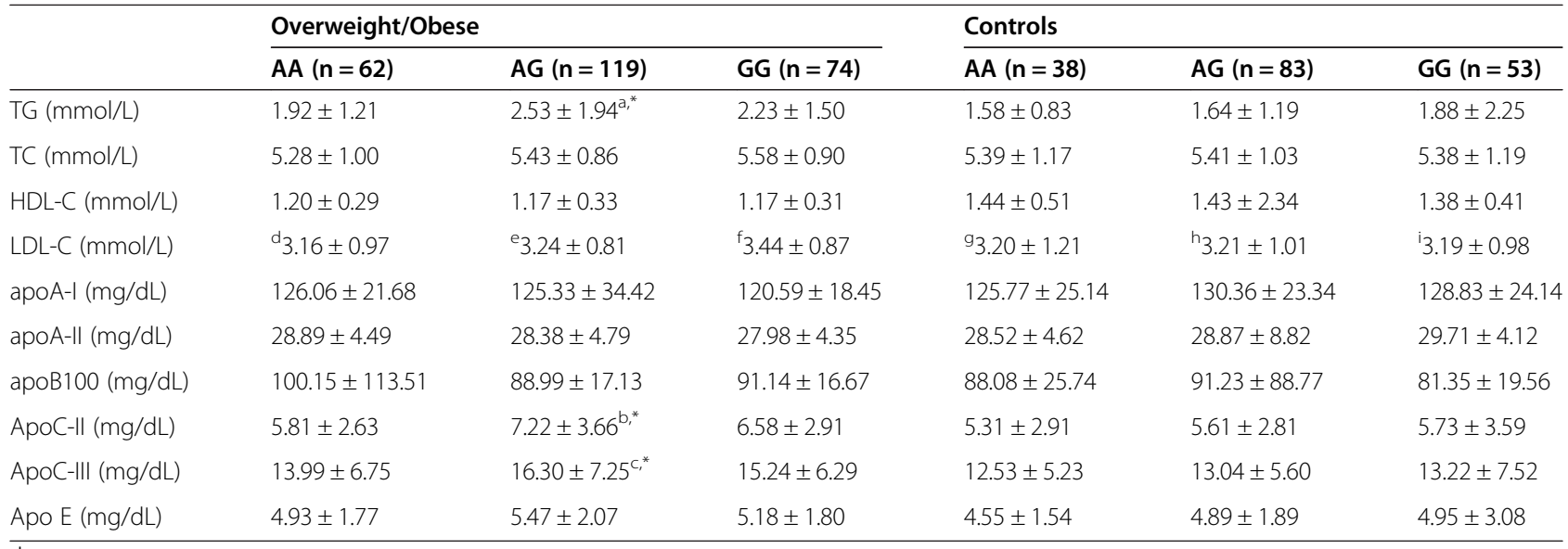

${ }^{\mathrm{abc} C o m p a r e d}$ with AA genotype carriers in the same group, respectively, ${ }^{*} \mathrm{p}<0.05$;

Subjects with TG $>4.516 \mathrm{mmol} / \mathrm{L}(400 \mathrm{mg} / \mathrm{dL})$ were excluded when calculating the serum LDL-C levels, ${ }^{d}: n=43,{ }^{e}: n=90,{ }^{f}: n=60,{ }^{g}: n=34,{ }^{h}: n=71,{ }^{i}: n=40$.

${ }^{\Delta}$ Age and sex were used as covariates in the analysis to adjust for the genotype effects.

$\beta 3-A R$ and $U C P 1$ are involved in the pathophysiology of metabolic disorders.

A total of 423 SNPs in $\beta 3-A R$ and 460 SNPs in UCP1 in both the coding and non-coding regions are available in the public database. Although to date the function of a substantial number of the SNPs in the genes has not been defined, those linked to protein coding substitutions

Table 5 Genotype and allele frequencies of the $\beta 3-A R$ Trp64Arg and UCP1 -3826 A > G polymorphisms according to HDL-C levels in the overweight/obese subjects

\begin{tabular}{|c|c|c|c|}
\hline & \multicolumn{3}{|l|}{ Frequencies } \\
\hline & $\begin{array}{l}\text { HDL-C }<1.04 \\
(n=101)\end{array}$ & $\begin{array}{l}\text { HDL-C } \geq 1.04 \\
(n=148)\end{array}$ & $P$ \\
\hline$\beta 3-A R$ Trp64Arg Genotype & & & $0.893^{\mathrm{a}}$ \\
\hline Trp Trp & $0.762(77)$ & $0.743(110)$ & \\
\hline Trp Arg & $0.228(23)$ & $0.250(37)$ & \\
\hline Arg Arg & $0.010(1)$ & $0.007(1)$ & \\
\hline Allele & & & 0.794 \\
\hline Trp & $1.752(177)$ & $1.736(257)$ & \\
\hline $\operatorname{Arg}$ & $0.248(25)$ & $0.264(39)$ & \\
\hline UCP1 -3826 A > G Genotype & & & $0.243^{b}$ \\
\hline AA & $0.198(20)$ & $0.291(43)$ & \\
\hline$A G$ & $0.485(49)$ & $0.446(66)$ & \\
\hline GG & $0.317(32)$ & $0.264(39)$ & \\
\hline Allele & & & 0.110 \\
\hline A & $0.881(89)$ & $1.027(152)$ & \\
\hline G & $1.119(113)$ & $0.973(144)$ & \\
\hline
\end{tabular}

Numbers in parentheses indicate the number of subjects with each genotype or number of alleles of each type.

${ }^{\mathrm{a}} \operatorname{Arg} A r g+\operatorname{TrpArg}$ vs. TrpTrp, $\chi^{2}=1.118$, odds radio $(\operatorname{Arg} \operatorname{Arg}+\operatorname{TrpArg} / \operatorname{TrpTrp})=$ $0.902,95 \%$ confidence interval 0.501-1.625.

${ }^{\mathrm{b}} \mathrm{GG}$ vs. $\mathrm{AA}+\mathrm{AG}, X^{2}=0.837$, odds radio $(\mathrm{GG} / \mathrm{AA}+\mathrm{AG})=1.296,95 \%$ confidence interval $0.743-2.261$. and in the introns, 5 ' and 3' UTRs related to the regulation of gene expression are of potential functional relevance. Among these SNPs, the most widely studied are the $\beta 3$ $A R$ Trp64Arg and UCP1 $-3826 \mathrm{~A}>\mathrm{G}$ due to their functional importance.

There have been many studies concerning the relationship between the Trp64Arg polymorphism of the $\beta 3-A R$ gene and obesity or related phenotypes; however, the results are inconsistent. Clement et al. [5] reported that Arg64 resulted in an increased tendency to accumulate weight in French subjects and that this polymorphism was also associated with obesity [8], difficulty in weight loss and a lower basal metabolic rate [27] in Japanese subjects. In contrast, Ghosh et al. [28] reported that the $\beta 3-A R$ polymorphism was not associated with obesity in a large Finnish sample population, and Shiwaku et al. also did not find an association with moderately overweight Japanese workers [29]. Our results are in line with the reports of Ghosh et al. and Shiwaku et al. The discrepancy among these studies may be caused by several factors, including environmental and genetic factors.

With respect to the effect of the $\beta 3-A R$ Trp64Arg polymorphism on lipids and apolipoproteins, Kim-Motoyama et al. [20] reported that the polymorphism was associated with obesity and decreased serum TG levels. Our results in overweight/obese Chinese are in line with the report. A previous report suggested that subjects with this mutation may be characterized by decreased lipolysis in visceral adipose tissues [20]. In the current study, we also found that the Arg allele carriers showed increased TC and apo AII concentrations compared to Trp allele carriers in the normal control subjects, which is in general consistent with the notion that the $\beta 3-A R$ polymorphism is associated with cholesterol metabolism, including a variation of HDL-C components such as apoA-II. We were unable to 
find a significant association between the polymorphism and HDL-C levels in our population, although reports have suggested that the Arg64 allele carriers of the $\beta 3$ $A R$ gene had decreased HDL-C levels in some populations $[19,20]$.

There are several reports available concerning the effect of the UCP1 -3826A > G polymorphism on obesity or plasma metabolic parameters. However, controversy remains because some reports do not support this role. For instance, Urhammer et al. [30] showed that the $U C P 1$ polymorphism was not associated with obesity in a Danish population, and Pihlajamaki et al. [31] reported that BMI and serum biochemistry were not significantly different based on UCP1 genotype in Finnish subjects with family combined hyperlipidemia. Schaffler et al. [26] showed that the G allele of $U C P 1$ was not associated with obesity and metabolic parameters in a large sample of German subjects. The current study is supportive of the results from the Danish, Finnish and German populations. Interestingly, we found that TG, apoC-II and apoC-III levels in overweight/obese subjects were elevated in AG genotype carriers compared with AA genotype carriers, suggesting a link between impaired metabolic levels in overweight/obese subjects and this polymorphism.

Kotani et al. reported that the UCP1 $-3826 \mathrm{~A}>\mathrm{G}$ polymorphism was associated with low HDL-cholesterolemia in obese Japanese patients [32]. In the current study we are unable to find a similar effect in overweight/obese subjects $(\mathrm{OR}=1.296, \mathrm{CI}=0.743-2.261, \mathrm{P}=0.360)$, suggesting that $U C P 1$ gene variation might not predispose overweight/obese Chinese subjects to the development of low HDL-cholesterolemia. Our result is in line with the reports in German Caucasians [26] and young Japanese males [33]. Interestingly, we found that other gene polymorphisms, such as $A B C A 1 \mathrm{R} 219 \mathrm{~K}$, were associated with low HDL-cholesterolemia in our overweight/obese subjects $(\mathrm{n}=206, \mathrm{OR}=2.243, \mathrm{CI}=1.232-4.083, \mathrm{P}=0.008)$ (data not shown), suggesting that genetic variant(s) other than UCP1 might predispose Chinese populations to low HDL-cholesterolemia.

Although the patient and control subjects participating in this study were randomized at enrollment into the respective overweight/obese and control groups, both groups had similar socioeconomic statuses (i.e., salary and education) and background environmental factors (i.e., diet and place of residence), and we attempted to control for some potential confounding factors such as age and sex in the data analyses, there might still have been some degree of uncontrolled confounding factors (i.e., smoking and forms of exercise). Future studies that examine whether any of these confounding factors additionally acted as effect modifiers on the relationship between the genotype and disease or related phenotypes will provide a more complete picture of genetic variations and the linked disease.
Finally, we should note that the difference in findings might reflect true variability in the association among different populations or ethnic groups. The above reports suggest that the role of the $\beta 3-A R$ and $U C P-1$ polymorphisms is complex. Obesity and related metabolic disorders may be determined by multiple factors, such as environmental and life style components, in addition to genetic components in which many candidates genes and their interactions may be involved.

\section{Conclusions}

The present study provides evidence that the $\beta 3-A R$ Trp64Arg and UCP1 -3826 A $>$ G polymorphisms are associated with TG levels in overweight/obese Chinese subjects and that the two polymorphisms are also associated with certain lipid and apolipoprotein variations, depending on BMI. However, these polymorphisms are not associated with overweight/obesity or low HDL-cholesterolemia in a Chinese population from the Chengdu area.

\section{Methods}

\section{Subjects}

For this study, blood samples were collected from 418 volunteers ( 242 men, 176 women, aged $53.77 \pm 11.29$ years) who were taking part in a routine health examination at the three hospitals of Sichuan University and Sichuan Normal University in Chengdu, China. All of these subjects were current or retired staff members of the Universities and were apparently healthy and unrelated individuals. After a 12 to 14 hour overnight fast, the blood from each individual was collected and analysed for serum concentrations of lipids, lipoproteins and apolipoproteins. BMI was calculated from height and weight measurements using the formula: $\mathrm{BMI}=$ body weight $/(\text { height })^{2}$ in $\mathrm{kg} / \mathrm{m}^{2}$. According to the World Health Organization guidelines for Asians, individuals with $B M I \geq 23 \mathrm{~kg} / \mathrm{m}^{2}$ are classified as overweight and those with $\mathrm{BMI} \geq 25 \mathrm{~kg} / \mathrm{m}^{2}$ are classified as obese [34]. Low HDL-cholesterolemia was defined as HDL-C $<1.04 \mathrm{mmol} / \mathrm{L}$ [35]. For the case-control study, 249 overweight/obese subjects (149 men, 100 women, aged $55.04 \pm 10.00$ years) with a BMI $\geq 23 \mathrm{~kg} / \mathrm{m}^{2}$ and 169 normal weight $(\mathrm{BMI}<23)$ subjects $(93$ men, 76 women, aged $53.35 \pm 11.78$ years) were used as the patients and controls, respectively. All of the subjects were Han Chinese living in the Chengdu area. Subjects with internal implications, such as $\mathrm{CHD}$, diabetes mellitus and hypertension, were excluded. All study participants provided their informed consent, and the study was approved by the institutional review board of the hospitals of Sichuan University and Sichuan Normal University.

\section{Quantitative analysis}

Total serum cholesterol (TC) and triglycerides (TGs) were measured by enzymatic methods (kits, Zhong Sen 
Co., Beijing). High density lipoprotein- cholesterol (HDL-C) was determined after sodium phosphotungstate/magnesium chloride precipitation of low-density lipoprotein by polyvinyl sulfate. Serum apo A-I, apoA-II, apo B100, apo C-II, apo C-III and apo E were quantified using a radial immunodiffusion kit developed by our laboratory [36]. The serum LDL-C concentration was calculated according to the Friedewald equation [37].

\section{DNA extraction and genotyping}

Genomic DNA was isolated from $500 \mu \mathrm{l}$ of peripheral blood according to the method of Erlich [38]. The PCRs were performed in a final volume of $25 \mu \mathrm{l}$ containing $10 \% 10 \times$ PCR buffer, $2 \mathrm{mM} \mathrm{MgCl}_{2}, 0.2 \mathrm{mM}$ dNTPs, $0.5 \mathrm{U}$ Taq DNA polymerase (MBI Fermentas) and $0.5 \mu \mathrm{M}$ of each sense and antisense primer. We used $100 \mathrm{ng}$ of DNA per PCR reaction. Genotypes for polymorphic $\beta 3-A R$ the Trp64Arg and UCP1 -3826 A > G polymorphisms were determined as previously described $[7,18]$.

\section{Statistical analysis}

Comparisons of continuous variables between two or more groups were performed with an independent $t$-test or one-way ANOVA, respectively. Allele frequencies of the beta3-AR and UCP1 gene polymorphisms were estimated by the gene counting method. Allele and genotype frequencies were compared between cases and controls by a chi-square test. Genotypes were also assessed according to the dominant and recessive genetic model. Each genetic model comprised two groups: the combined group of variant homozygotes and heterozygotes vs wild-type homozygotes for the dominant model; and variant homozygotes vs the combined group of wild-type homozygotes and heterozygotes for the recessive model. Multiple logistic regression analysis with a stepwise forward selection procedure was performed to calculate odds ratios (OR) with obesity as a dependent variable and genotype according to the above genetic models in the presence of confounders (age and sex) as independent variables. Differences were considered statistically significant at a p-value $<0.05$. The statistical analyses were performed using the Statistical Package for Social Sciences (SPSS 11.0 for Windows).

\section{Abbreviations}

B3-AR: Beta-3 adrenergic receptor; UCP1: Uncoupling protein 1; TC: Total cholesterol; TG: Triglycerides; HDL-C: High density lipoprotein-cholesterol; LDL-C: Low density lipoprotein-cholesterol; apo: Apolipoprotein; PCR-RFLP: Polymerase chain reaction-restriction fragment length polymorphisms; OR: Odds ratio; BMI: Body mass index.
}

\section{Competing interests}

The authors declare that they have no competing interests.

\section{Authors' contributions}

YC and PF contributed with clinical data collection; XW, ZS, YL and LM performed the laboratory experiments; RL and $\mathrm{HB}$ contributed with study design; RL, RR and HB performed the statistical analysis and wrote the paper. All the authors read and approved the final manuscript.

\section{Acknowledgements}

This work was supported by a grant from the National Natural Sciences Foundation of China (No.39770322), the Program for Changjiang Scholars and Innovative Research Team in University (IRT0935), and the Research Seed Fund from West China Second University Hospital of Sichuan University. The authors thank the overweight/obese and control subjects who donated blood samples for this study. There are no conflicts of interest.

\section{Author details}

${ }^{1}$ Laboratory of Genetic Disease and Perinatal Medicine and Key Laboratory of Birth Defects and Related Diseases of Women and Children of Ministry of Education, West China Second University Hospital, Sichuan University, Chengdu 610041, Sichuan, PR China. ${ }^{2}$ Division of Peptides related with Human Disease, West China Hospital, Sichuan University, Chengdu 610041, Sichuan, People's Republic of China. ${ }^{3}$ Department of Biochemistry and Molecular Biology, West China School of Preclinical and Forensic Medicine, Sichuan University, Chengdu 610041, Sichuan, PR China.

Received: 4 December 2014 Accepted: 1 April 2015

Published online: 20 April 2015

\section{References}

1. Barsh GS, Schwartz MW. Genetic approaches to studying energy balance: perception and integration. Nat Rev Genet. 2002;3(8):589-600.

2. Emorine L, Marullo S, Briend-Sutren MM, Patey G, Tate K, Delavier-Klutchko $\mathrm{C}$, et al. Molecular characterization of the human beta3-adrenergic receptor. Science. 1989;245(4922):1118-21.

3. Nagase I, Yoshida T, Kumamoto K, Umekawa T, Sakane N, Nikami H, et al. Expression of uncoupling protein in skeletal muscle and white fat of obese mice treated with thermogenic beta3-adrenergic agonist. J Clin Invest. 1996;97(12):2898-904.

4. Yoshida T, Umekawa T, Kumamoto K, Sakane N, Kogure A, Kondo M, et al. Beta3-adrenergic agonist induces a functionally active uncoupling protein in fat and slow-twitch muscle fibers. Am J Physiol. 1998;274(3 Pt 1):E469-75.

5. Clément K, Vaisse C, Manning BS, Basdevant A, Guy-Grand B, Ruiz J, et al. Genetic variation in the $\beta 3$-adrenergic receptor and an increased capacity to gain weight in patients with morbid obesity. N Engl J Med. 1995;333(6):352-4.

6. Miyaki K, Sutani S, Kikuchi H, Takei I, Murata M, Watanabe K, et al. Increased risk of obesity resulting from the interaction between high energy intake and the Trp64Arg polymorphism of the beta3-adrenergic receptor gene in healthy Japanese men. J Epidemiol. 2005;15(6):203-10.

7. Widen E, Lehto M, Kanninen T, Walston J, Schuldiner AR, Groop LC. Association of a polymorphism in the $\beta 3$-adrenergic receptor gene with features of the insulin resistance syndrome in Finns. N Engl J Med. 1995;333(6):348-51.

8. Kadowaki H, Yasuda K, Iwamoto K, Otabe S, Shimokawa K, Silver K, et al. A mutation in the beta 3 -adrenergic receptor gene is associated with obesity and hyperinsulinemia in Japanese subjects. Biochem Biophys Res Commun. 1995;215(2):555-60.

9. Klaus S, Casteilla L, Bouillaud F, Ricquier D. The uncoupling protein UCP: a membraneous mitochondrial ion carrier exclusively expressed in brown adipose tissue. Int J Biochem. 1991;23(9):791-801.

10. Bouillaud F, Couplan E, Pecqueur C, Ricquier D. Homologues of the uncoupling protein from brown adipose tissue (UCP-1): UCP2, UCP3, BMCP1 and UCP4. Biochim Biophys Acta. 2001;1504(1):107-19.

11. Park MJ. Recent advances in regulating energy homeostasis and obesity. Korean J Pediatr. 2005;48(2):126-37.

12. Nagai N, Sakane N, Kotani K, Hamada T, Tsuzaki K, Moritani T. Uncoupling protein 1 gene $-3826 \mathrm{~A} / \mathrm{G}$ polymorphism is associated with weight loss on a short term, controlled-energy diet in young women. Nutr Res. 2011;31(4):255-61.

13. Oppert JM, Vohl MC, Chagnon M, Dionne FT, Cassard-Doulcier AM, Ricquier D, et al. DNA polymorphism in the uncoupling protein (UCP) gene and human body fat. Int J Obes Relat Metab Disord. 1994;18(8):526-31.

14. Fumeron F, Durack-Bown I, Betoulle D, Cassard-Doulcier AM, Tuzet S, Bouillaud F, et al. Polymorphisms of uncoupling protein (UCP) and beta 3 adrenoreceptor genes in obese people submitted to a low calorie diet. Int J Obes Relat Metab Disord. 1996;20(12):1051-4.

15. Proenza AM, Poissonnet CM, Ozata M, Ozen S, Guran S, Palou A, et al. Association of sets of alleles of genes encoding beta3-adrenoreceptor, 
uncoupling protein 1 and lipoprotein lipase with increased risk of metabolic complications in obesity. Int J Obes Relat Metab Disord. 2000;24(1):93-100.

16. Esterbauer H, Oberkofler H, Liu YM, Breban D, Hell E, Krempler F, et al. Uncoupling protein-1 mRNA expression in obese human subjects: the role of sequence variations at the uncoupling protein-1 gene locus. J Lipid Res. 1998:39(4):834-44

17. Kieć-Wilk B, Wybrańska I, Malczewska-Malec M, Leszczyńska-Gołabek L, Partyka L, Niedbał S, et al. Correlation of the $-3826 \mathrm{~A}>\mathrm{G}$ polymorphism in the promoter of the uncoupling protein 1 gene with obesity and metabolic disorders in obese families from southern Poland. J Physiol Pharmacol. 2002;53(3):477-90

18. Oh HH, Kim KS, Choi SM, Yang HS, Yoon Y. The effects of uncoupling protein-1 genotype on lipoprotein cholesterol level in Korean obese subjects. Metabolism. 2004;53(8):1054-9.

19. Thomas GN, Tomlinson B, Chan JC, Young RP, Critchley JA. The Trp64Arg polymorphism of the beta3-adrenergic receptor gene and obesity in Chinese subjects with components of the metabolic syndrome. Int J Obes Relat Metab Disord. 2000;24(5):545-51.

20. Kim-Motoyama H, Yasuda K, Yamaguchi T, Yamada N, Katakura T, Shuldiner $A R$, et al. A mutation of the beta 3-adrenergic receptor is associated with visceral obesity but decreased serum triglyceride. Diabetologia. 1997:40(4):469-72.

21. Odawara M, Sasaki K, Yamashita K. $\beta 3$-adrenergic receptor gene variant and Japanese NIDDM: a pitfall in meta-analysis. Lancet. 1996;348(9031):896-7.

22. Buettner R, Schsffler A, Arndt H, Rogler G, Nusser J, Zietz B, et al. The Trp64Arg polymorphism of the $\beta 3$-adrenergic receptor gene is not associated with obesity or type 2 diabetes mellitus in a large population-based Caucasian cohort. J Clin Endocrinol Metab. 1998;83(8):2892-7.

23. Matsushita Y, Yokoyama T, Yoshiike N, Matsumura Y, Date C, Kawahara K et al. The Trp64Arg polymorphism of the $\beta 3$-adrenergic receptor gene is not associated with body weight or body mass index in Japanese: a longitudinal analysis. J Clin Endocrinol Metab. 2003;88(12):5914-20.

24. Matsushita H, Kurabayashi T, Tomita M, Kato N, Tanaka K. Effects of uncoupling protein 1 and $\beta 3$-adrenergic receptor gene polymorphism on body size and serum lipid concentrations in Japanese women. Maturitas. 2003;45(1):39-45

25. Kotani K, Sakane N, Kurozawa Y, Kaetsu A, Okamoto M, Osaki Y, et al. Polymorphism of Trp64Arg in beta3-adrenergic receptor gene and serum LDL-cholesterol concentrations in healthy Japanese. Ann Clin Biochem 2008;45(Pt 3):313-5.

26. Schaffler A, Palitzsch KD, Watzlawek E, Drobnik W, Schwr H, Schölmerich J, et al. Frequency and significance of the $A>G(-3826)$ polymorphism in the promoter of the gene for uncoupling protein-1 with regard to metabolic parameters and adipocyte transcription factor binding in a large population-based Caucasian cohort. Eur J Clin Invest. 1999;29(9):770-9.

27. Yoshida T, Sakane N, Umekawa T, Sakai M, Takahashi T, Kondo M. Mutation of beta 3-adrenergic-receptor gene and response to treatment of obesity. Lancet. 1995;346(8987):1433-4.

28. Ghosh S, Langefeld CD, Ally D, Watanabe RM, Hauser ER, Magnuson VL, et al. The W64R variant of the beta3-adrenergic receptor is not associated with type II diabetes or obesity in a large Finnish sample. Diabetologia. 1999;42(2):238-44.

29. Shiwaku K, Gao TQ, Isobe A, Fukushima T, Yamane Y. A Trp 64 Arg mutation in the beta3-adrenergic receptor gene is not associated with moderate overweight in Japanese workers. Metabolism. 1998;47(12):1528-30.

30. Urhammer SA, Fridberg M, Sørensen TI, Echwald SM, Andersen T, Tybjaerg-Hansen A, et al. Studies of genetic variability of the uncoupling protein 1 gene in Caucasian subjects with juvenile-onset obesity. J Clin Endocrinol Metab. 1997;82(12):4069-74.

31. Pihlajamäki J, Rissanen J, Valve R, Heikkinen S, Karjalainen L, Laakso M. Different regulation of free fatty acid levels and glucose oxidation by the Trp64Arg polymorphism of the beta3-adrenergic receptor gene and the promoter variant (A-3826G) of the uncoupling protein 1 gene in familial combined hyperlipidemia. Metabolism. 1998;47(11):1397-402.

32. Kotani K, Fujiwara S, Tsuzaki K, Sano Y, Nagai N, Yamada T, et al. The association between the uncoupling protein-1 gene a-3826g polymorphism and high-density lipoprotein cholesterol in a general japanese population: a consideration of the obesity status. J Clin Med Res. 2011;3(6):319-24.

33. Nakano $T$, Shinka $T$, Sei $M$, Sato $Y$, Umeno $M$, Sakamoto $K$, et al. A/G heterozygote of the A-3826G polymorphism in the UCP-1 gene has higher
BMI than $\mathrm{A} / \mathrm{A}$ and $\mathrm{G} / \mathrm{G}$ homozygote in young Japanese males. J Med Invest. 2006;53(3-4):218-22

34. WHO Expert Consultation. Appropriate body-mass index for Asian populations and its implications for policy and intervention strategies. Lancet. 2004;363(9403):157-63.

35. Teramoto T, Sasaki J, Ueshima H, Egusa G, Kinoshita M, Shimamoto K, et al. Diagnostic criteria for dyslipidemia. Executive summary of Japan Atherosclerosis Society (JAS) guidelines for diagnosis and prevention of atherosclerotic cardiovascular diseases for Japanese. J Atheroscler Thromb. 2007;14(4):155-8.

36. Liu BW. Enzymatic method and radial immunodiffusion measurement and its application in clinical aspects. In: Wang Keqing, Lipoprotein and atherosclerosis. 1st ed. Beijing: People's Health Publish House; 1995. p. 359-60.

37. Friedewald WT, Levy RI, Fredrickson DS. Estimation of the concentration of low-densitry lipoprotein cholesterol in plasma, without use of the preparative ultracentrifuge. Clin Chem. 1972;18(6):499-502.

38. Erlich HA. Principles and Applications for DNA Amplification. 1st ed. New York: Stockton; 1989. p. 36. PCR Technology; p.36.

\section{Submit your next manuscript to BioMed Central and take full advantage of:}

- Convenient online submission

- Thorough peer review

- No space constraints or color figure charges

- Immediate publication on acceptance

- Inclusion in PubMed, CAS, Scopus and Google Scholar

- Research which is freely available for redistribution 